\title{
7-Methoxy-8-Prenylated Coumarins from Murraya koenigi (Linn.) Spreng.
}

\author{
Md. Mubarak Hossain ${ }^{1}$, Faiza Tahia ${ }^{1}$, Md. Abdullah Al-Mansur ${ }^{2}$ and \\ Mohammad A. Rashid ${ }^{1}$
}

\author{
${ }^{1}$ Phytochemical Research Laboratory, Department of Pharmaceutical Chemistry, Faculty of Pharmacy, \\ University of Dhaka, Dhaka-1000, Bangladesh \\ ${ }^{2}$ Bangladesh Council of Scientific and Industrial Research (BCSIR), Dr. Qudrat-I-Khuda Road, \\ Dhanmondi, Dhaka-1205, Bangladesh
}

(Received: September 16, 2016; Accepted: October 10, 2016; Published (web): December 27, 2016)

\begin{abstract}
Four coumarin derivatives were isolated from the methanol extract of stem bark of Murraya koenigii (Linn.) Spreng. Extensive spectroscopic studies, including high field NMR analyses allowed to identify these compounds as meranzin hydrate (1), epoxyosthol (2), isomeranzin (3) and murracarpin (4). The identity of the compounds was confirmed by comparison with published data as well as co-TLC with authentic samples. This is the first report of occurrence of meranzin hydrate (1), epoxyosthol (2) and isomeranzin (3) from M. koenigii.
\end{abstract}

Key words: Murraya koenigii, Rutaceae, meranzin hydrate, epoxyosthol, isomeranzin, murracarpin.

\section{INTRODUCTION}

Murraya koenigii (Linn.) Spreng. (Bengali name- Chotokamini; Family- Rutaceae) is more or less a deciduous small tree up to 6 meters in height and widely distributed throughout Bangladesh. ${ }^{1}$ The plant has a short trunk of $15-40 \mathrm{~cm}$ in diameter ${ }^{2}$ and the main stem is dark green to brownish in colour. ${ }^{3}$ M. koenigii is a medicinal plant, various parts of which have been traditionally used in diabetes, skin eruptions, poisonous bites, febrifuge and dysentery. ${ }^{4}$ It has been medicinally important for its antimicrobial, anthelmintic, anti-inflammatory and hypoglecemic properties. ${ }^{5}$ Previous phytochemical studies with the alcohol extract of stem bark of $M$. koenigii provided koenigine-quinone $\mathrm{A}$, koeniginequinone $\mathrm{B}^{6}$, 9-carbethoxy-3-methylcarbazole, 9formyl-3-methylcarbazole ${ }^{7}$, methyl-2-methoxycarbazole-3-carboxylate and 1-hydroxy-3-methyl carbazole. ${ }^{8}$ Mukonal, a biogenetic intermediate of pyranocarbazole alkaloid was also detected in the

Correspondence to: Mohammad A. Rashid

Tel.: +88-02-9661900-73, Extn.- 8137; Fax: +88-02-9667222;

E-mail: rashidma@du.ac.bd

Dhaka Univ. J. Pharm. Sci. 15(2): 155-159, 2016 (December) stem bark of $M$. koenigii. $^{8}$ In addition, alkaloids, coumarin and cinnamic acid derivative from the plant have also been previously isolated and characterizied. $^{9}$ Marmesin-1'-O- $\beta$-D-galactopyranoside, osthol and umbelliferone ${ }^{10}$ and $3-(1,1-$ dimethylallyl) xanthyletin have also been isolated from petroleum ether extract of the stem bark of $M$. koenigii. ${ }^{11}$

As part of our onging studies with medicinal plants of Bangladesh ${ }^{9,}{ }^{12-16}$, the stem bark of $M$. koenigii was subjected to chemical investigation and we, herein, describe the isolation and structure elucidation of meranzin hydrate (1), epoxyosthol (2), isomeranzin (3) and murracarpin (4), where epoxyosthol (2) and coumarins 1-3 have also been reported from $M$. koenigii for the first time.

\section{MATERIALS AND METHODS}

General experimental procedures. ${ }^{1} \mathrm{H}$ NMR spectra were acquired on Ultra Shield Bruker 400 NMR instrument, using $\mathrm{CDCl}_{3}$ and the chemical shifts are reported in ppm with respect to TMS or 
residual non deuterated solvent signals. All solvents and reagents are of highest analytical grade.

Plant material. Stem bark of M. koenigii were collected from Curzon Hall area, University of Dhaka, Bangladesh, in November 2014. The plant was taxonomically identified in Bangladesh National Herbarium, Dhaka, where a voucher specimen (DACB no. 43870) for the plant has been maintained for future reference. The stem bark was first sun dried and then ground into coarse powder.

Extraction and isolation. The air dried and powdered stem bark $(1.0 \mathrm{~kg})$ was soaked in $3.0 \mathrm{~L}$ methanol for 15 days and then filtered through a cotton plug followed by Whatman filter paper number 1 . The extract was concentrated with a rotary evaporator. A portion $(5 \mathrm{~g})$ of the concentrated methanol extract was partitioned by the modified Kupchan partitioning protocol ${ }^{21}$ into petroleum ether $(0.65 \mathrm{~g})$, dichloromethane $(0.55 \mathrm{~g})$, ethyl acetate $(0.30 \mathrm{~g})$ and aqueous $(2.5 \mathrm{~g})$ soluble material.

The dichloromethane soluble partitionate was subjected to gel permeation chromatography over Lipophilic Sephadex LH-20 using $n$-hexanedichloromethane-methanol $(2: 5: 1)$ and a total of 30 fractions were collected, each of $20 \mathrm{ml}$. On the basis of their TLC behavior, fraction 14, 19 and 25 were subjected to preparative thin layer chromatography (PTLC) over silica gel (Kiselgel $\mathrm{F}_{254}$ ) using mobile phase comprising of $40 \%$ ethyl acetate in toluene to yield meranzinhydrate (1), epoxyosthol (2), isomeranzin (3) and murracarpin (4).

\section{Properties of isolated compounds}

Meranzin hydrate (1): colourless mass; ${ }^{1} \mathrm{H}$ NMR (400 MHz, $\left.\mathrm{CDCl}_{3}\right): \delta 1.32\left(3 \mathrm{H}, \mathrm{s}, 5^{\prime}-\mathrm{Me}\right), 1.33$ (3H, s, 4'-Me), 2.99 (1H, d, $\left.J=13.6 \mathrm{~Hz}, \mathrm{H}-1^{\prime}\right), 3.11$ $\left(1 \mathrm{H}, \mathrm{d}, J=13.2 \mathrm{~Hz}, \mathrm{H}-1^{\prime}\right), 3.64(1 \mathrm{H}, \mathrm{d}, J=10 \mathrm{~Hz}, \mathrm{H}-$ $\left.2^{\prime}\right), 3.93$ (3H, s, 7-OMe), $6.25(1 \mathrm{H}, \mathrm{d}, J=9.6 \mathrm{~Hz}, \mathrm{H}-$ 3), $6.87(1 \mathrm{H}, \mathrm{d}, J=8.4 \mathrm{~Hz}, \mathrm{H}-6), 7.35(1 \mathrm{H}, \mathrm{d}, J=8.4$ $\mathrm{Hz}, \mathrm{H}-5), 7.63(1 \mathrm{H}, \mathrm{d}, J=9.6 \mathrm{~Hz}, \mathrm{H}-4)$.

Epoxyosthol (2): white crystalline mass; ${ }^{1} \mathrm{H}$ NMR (400 MHz, $\left.\mathrm{CDCl}_{3}\right): \delta 1.28\left(3 \mathrm{H}, \mathrm{s}, 5^{\prime}-\mathrm{Me}\right), 1.49$ (3H, s, 4'-Me), $3.02\left(2 \mathrm{H}, \mathrm{m}, \mathrm{H}_{2}-1^{\prime}\right), 3.17$ (1H, brd, $J$ $\left.=7.6 \mathrm{~Hz}, \mathrm{H}-2^{\prime}\right), 3.93(3 \mathrm{H}, \mathrm{s}, 7-\mathrm{OMe}), 6.23(1 \mathrm{H}, \mathrm{d}, J$ $=9.2 \mathrm{~Hz}, \mathrm{H}-3), 6.87(1 \mathrm{H}, \mathrm{d}, J=8.4 \mathrm{~Hz}, \mathrm{H}-6), 7.35$
$(1 \mathrm{H}, \mathrm{d}, J=8.4 \mathrm{~Hz}, \mathrm{H}-5), 7.63(1 \mathrm{H}, \mathrm{d}, J=9.2 \mathrm{~Hz}, \mathrm{H}-$ $4)$.

Isomeranzin (3): colourless mass; ${ }^{1} \mathrm{H}$ NMR $\left(400 \mathrm{MHz}, \mathrm{CDCl}_{3}\right): \delta 1.20\left(6 \mathrm{H}, \mathrm{d}, J=6.8 \mathrm{~Hz}, \mathrm{H}-4^{\prime}\right.$ and $\left.\mathrm{H}-5^{\prime}\right), 2.81\left(1 \mathrm{H}, \mathrm{m}, \mathrm{H}-3^{\prime}\right), 3.86(3 \mathrm{H}, \mathrm{s}, 7-\mathrm{OMe})$, $4.00\left(2 \mathrm{H}, \mathrm{s}, \mathrm{H}_{2}-1^{\prime}\right), 6.22(1 \mathrm{H}, \mathrm{d}, J=9.6 \mathrm{~Hz}, \mathrm{H}-3)$, $6.84(1 \mathrm{H}, \mathrm{d}, J=8.8 \mathrm{~Hz}, \mathrm{H}-6), 7.37(1 \mathrm{H}, \mathrm{d}, J=8.8 \mathrm{~Hz}$, $\mathrm{H}-5), 7.62(1 \mathrm{H}, \mathrm{d}, J=9.6 \mathrm{~Hz}, \mathrm{H}-4)$.

Murracarpin (4): colourless mass; ${ }^{1} \mathrm{H}$ NMR $\left(400 \mathrm{MHz}, \mathrm{CDCl}_{3}\right): \delta 1.68\left(3 \mathrm{H}, \mathrm{s}, 5^{\prime}-\mathrm{Me}\right), 3.32(3 \mathrm{H}$, s, 1'-OMe), $3.92(3 \mathrm{H}, \mathrm{s}, 7-\mathrm{OMe}), 4.63(1 \mathrm{H}$, brs, H4'), $4.69(1 \mathrm{H}$, brs, H-4'), $4.92(1 \mathrm{H}, \mathrm{d}, J=8.8 \mathrm{~Hz}, \mathrm{H}-$ 2'), $5.04\left(1 \mathrm{H}, \mathrm{d}, J=8.8 \mathrm{~Hz}, \mathrm{H}-1^{\prime}\right), 6.25(1 \mathrm{H}, \mathrm{d}, J=$ $9.6 \mathrm{~Hz}, \mathrm{H}-3), 6.85(1 \mathrm{H}, \mathrm{d}, J=8.8 \mathrm{~Hz}, \mathrm{H}-6), 7.39(1 \mathrm{H}$, d, $J=8.8 \mathrm{~Hz}, \mathrm{H}-5), 7.61(1 \mathrm{H}, \mathrm{d}, J=9.6 \mathrm{~Hz}, \mathrm{H}-4)$.

\section{RESULTS AND DISCUSSION}

A total of four compounds (1-4) were isolated from dichloromethane soluble partitionate of methanol extract of stem bark of M. koenigii by gel permeation chromatography over lipophilic Sephadex LH-20 followed by preparative thin layer chromatography (PTLC) using silica gel (Kiselgel $\mathrm{F}_{254}$ ). The structure of the isolated compounds was solved by extensive analyses of their high resolution ${ }^{1} \mathrm{H}-\mathrm{NMR}$ spectroscopic data as well as by comparison with published values.

The ${ }^{1} \mathrm{H}$ NMR (400 $\mathrm{MHz}, \mathrm{CDCl}_{3}$ ) spectrum of compound 1 demonstrated the presence of 7methoxy-8-substituted coumarin type carbon skeleton for which two sets of AB doublets at $\delta 7.63(J=9.6$ $\mathrm{Hz})$ and $6.25(J=9.6 \mathrm{~Hz})$ and at $\delta 7.35(J=8.4 \mathrm{~Hz})$ and $6.87(J=8.4 \mathrm{~Hz})$ and a methoxy singlet at $\delta$ 3.93 were observed. Furthermore, the presence of a gem-dimethyl group of hydroxy-isopropyl substituent was revealed by two singlets at $\delta 1.32$ and $1.33 \mathrm{ppm}$. The spectrum also displayed two doublets for methylene proton at $\delta 3.11(\mathrm{~J}=13.4 \mathrm{~Hz})$ and $2.99(\mathrm{~J}$ $=13.4 \mathrm{~Hz}$ ) and another doublet for the methine at $\delta$ $3.64(J=10 \mathrm{~Hz})$. Therefore, the side chain at C-8 position was readily elucidated as $\mathrm{CH}_{2} \mathrm{CH}(\mathrm{OH}) \mathrm{C}\left(\mathrm{CH}_{3}\right)_{2} \mathrm{OH}$. These spectral features are in close agreement to that published for meranzin hydrate ${ }^{17}$. Thus, compound $\mathbf{1}$ was characterized as 
meranzin hydrate, which was further confirmed by co-TLC with an authentic sample. Although meranzin hydrate (1) has previously been isolated

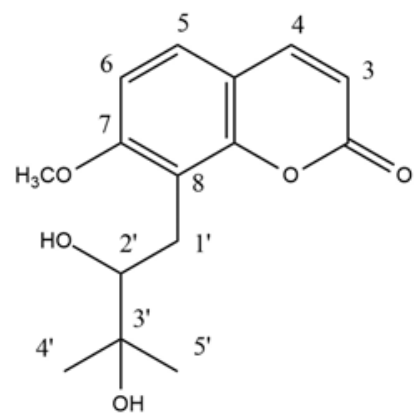

Meranzin hydrate (1)

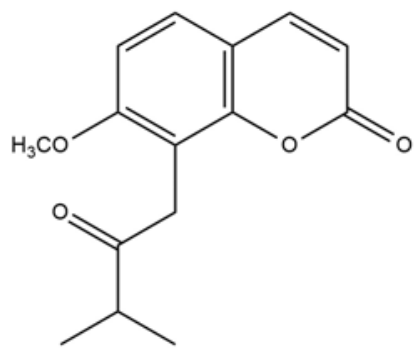

Isomeranzin (3)

The ${ }^{1} \mathrm{H}$ NMR $\left(400 \mathrm{MHz}, \mathrm{CDCl}_{3}\right)$ spectrum of compound 2 showed two $\mathrm{AB}$ quartets with proton signals centered at $\delta 6.23(\mathrm{~d}, 1 \mathrm{H}, J=9.2 \mathrm{~Hz}), 7.63(\mathrm{~d}$, $1 \mathrm{H}, J=9.2 \mathrm{~Hz}), 7.35(\mathrm{~d}, 1 \mathrm{H}, J=8.4 \mathrm{~Hz})$ and $6.87(\mathrm{~d}$, $1 \mathrm{H}, J=8.4 \mathrm{~Hz}$ ) which could be attributed to $\mathrm{H}-3, \mathrm{H}-4$, $\mathrm{H}-5$ and $\mathrm{H}-6$, respectively. The broad doublet that integrated for one proton at $\delta 3.17(J=7.6 \mathrm{~Hz})$ could be assigned to H-2' of the epoxy ring. The multiplets of two proton intensity at $3.02 \mathrm{ppm}$ was ascribed to the protons of the methylene group at $\mathrm{C}-1$ ' position. A singlet of three protons intensity at $\delta 3.93$ could be assigned to the methoxyl group at C-7 of the coumarin skeleton. Another three proton singlet at $\delta$ 1.49 was assigned to the methyl group at C-4' position which is nearer to the oxygen atom of the epoxy ring. The second methyl signal at $\delta 1.28 \mathrm{ppm}$ could be attributed to the remaining methyl protons at C-5' position, which is away from the epoxy ring. On this basis, compound 2 was characterized as from many plants belonging to the family Rutaceae ${ }^{17}$, this is the first report of its occurrence from Murraya koenigii.<smiles>COc1ccc2ccc(=O)oc2c1CC1OC1(C)C</smiles>

Epoxyosthol (2)<smiles>C=C(C)C(O)C(OC)c1c(OC)ccc2ccc(=O)oc12</smiles>

Murracarpin (4)

epoxyosthol and its identity was further confirmed by comparing its ${ }^{1} \mathrm{H}$ NMR spectral data to that of the published values ${ }^{18}$. This is the first report of the isolation of epoxyosthol (2) from M. koenigii.

The ${ }^{1} \mathrm{H}$ NMR (400 MHz, $\mathrm{CDCl}_{3}$ ) spectrum of compound 3 displayed proton signals at $\delta 6.22(\mathrm{~d}$, $1 \mathrm{H}, J=9.6 \mathrm{~Hz}), 7.62(\mathrm{~d}, 1 \mathrm{H}, J=9.6 \mathrm{~Hz}), 7.37$ (d, $1 \mathrm{H}$, $J=8.8 \mathrm{~Hz})$ and $\delta 6.84(\mathrm{~d}, 1 \mathrm{H}, J=8.8 \mathrm{~Hz})$ assignable to H-3, H-4, H-5 and H-6, of a coumarin type carbon skeleton, respectively. The singlet that integrated for two protons at $\delta 4.00 \mathrm{ppm}$ could be assigned to the $\mathrm{C}$ 1 ' methylene protons of the 3'-methyl-2'-oxobutyl side chain at $\mathrm{C}-8$. The multiplet of one proton intensity at $\delta 2.81 \mathrm{ppm}$ was accounted for the proton at $\mathrm{C}-3$ ' position. The methoxyl protons at C-7 resonated at $\delta 3.86 \mathrm{ppm}$. A doublet that integrated for six protons at $\delta 1.20(J=6.8 \mathrm{~Hz})$ could be assigned to the methyl groups at $\mathrm{C}-3^{\prime}$ position. On the basis of the above spectral data, compound $\mathbf{3}$ was identified as 
isomeranzin ${ }^{19}$, which has been further confirmed by co-TLC with a previously isolated sample. This is also the first report of its occurrence from this plant.

The ${ }^{1} \mathrm{H}$ NMR (400 MHz, $\mathrm{CDCl}_{3}$ ) spectrum of compound 4 showed an $\mathrm{AB}$ pattern with proton resonances at $\delta 6.25(\mathrm{~d}, 1 \mathrm{H}, J=9.6 \mathrm{~Hz}), 7.61(\mathrm{~d}, 1 \mathrm{H}$, $J=9.6 \mathrm{~Hz}), 7.39(\mathrm{~d}, 1 \mathrm{H}, J=8.8 \mathrm{~Hz})$ and $6.85(\mathrm{~d}, 1 \mathrm{H}$, $J=8.8 \mathrm{~Hz}$ ) for H-3, H-4, H-5 and H-6, respectively of the coumarin nucleus. The doublets that integrated for one proton each at $\delta 5.04(J=8.8 \mathrm{~Hz})$ and 4.92 $(J=8.8 \mathrm{~Hz})$ were assigned to $\mathrm{H}-1^{\prime}$ and $\mathrm{H}-2$ ' position of the hydrocarbon chain, respectively. Two singlets, each of three proton intensity, at $\delta 3.92$ and 3.32 could be demonstrated to the methoxy group at C-7 of the coumarin skeleton and to the aliphatic methoxyl group at $\mathrm{C}-1$ ' position of the hydrocarbon chain, respectively. Another singlet for three protons at $\delta 1.68 \mathrm{ppm}$ was assigned to the methyl protons at C-5' of the side chain C-8. Two broad singlets, each of one proton intensity, at $\delta 4.63$ and 4.69 can be accounted for the protons of the exo-methylene group at $\mathrm{C}-4$ ' position.

Thus, the structure of compound $\mathbf{4}$ was solved as murracarpin which was further supported by comparing its ${ }^{1} \mathrm{H}$ NMR spectral data with reported values $^{20}$ as well as by co-TLC with an authentic sample. Murracarpin (4) has previously been reported from M. koenigii.

\section{ACKNOWLEDGMENTS}

One of us (MAR) is grateful to the Ministry of Education, Government of the People's Republic of Bangladesh and University Grants Commission, Bangladesh for financial support to establish the laboratory facilities through research grants (for the period 2014-15 to 2016-17 Ref: 2014-15/13) and Higher Education Quality Enhancement Project (HEQEP), AIF, Round-III, Window-2, CP-3258, Award No. 141, (Contact \# 43/2014), respectively where part of the research work was conducted.

\section{REFERENCES}

1. Biswas, A. 2006. Indigenous knowledge of herbal medicine and in vitro propagation of some rare medicinal plants in
Chittagong hill tracts. PhD dissertation. Rajshahi University, Rajshahi, Bangladesh.

2. Mhaskar, K.S., Blatter, E., Caius, J.F., Kirtikar. Basu's Illustrated Indian Medicinal Plants, Vol. I, $3^{\text {rd }}$ edn., Indian Medical Science Series 2000, pp. 86-96.

3. Raghunathan, K., Mitra, R. 1982. Pharmacognosy of Indigenous Drugs. Central Council For Research in Ayurveda and Siddha, New Delhi, India.1, p.433.

4. Chowdhury, J.U., Bhuiyan, M.N.I. and Yusuf, M. 2008. Chemical components of the leaf essential oils of Murraya koenigii (L.) Spreng. and Murraya paniculata (L.) Jack. Bangladesh J. Pharmacol. Soc. 3, 59-63.

5. Handral, H.K., Pandith, A. and Shruthi, S.D. 2012. A review on Murraya koenigii: multipotential medicinal plant. Asian $J$. Pharm. Clin. Res. 5, 5-14.

6. Saha, C. and Chowdhury, B.K. 1998. Carbazoloquinones from Murraya koenigii. Phytochemistry 48, 363-366.

7. Chakraborty, M., Nath, A.C., Khasnobis, S., Chakraborty, M., Konda, Y. and Harigaya, Y. 1997. Carbazole alkaloids from Murraya koenigii. Phytochemistry 46, 751-755.

8. Bhattacharya, P., Maiti, A.K., Basu, K. and Chowdhury, B.K. 1994. Carbazole alkaloids from Murraya koenigii. Phytochemistry. 35, 1085-1086.

9. Tahia, F., Sikder, M.A., Haque, M.R., Shilpi, J.A., Awang, K., Mansur, M.A. and Rashid, M.A. 2015. Alkaloids, coumarin and cinnamic acid derivative from Murraya koenigii (L.) Spreng. Dhaka Univ. J. Pharm. Sci. 14, 29-33.

10. Jain, R.K. and Srivstava, S.D. 1992. Anti-inflammatory, antimicrobial and phytochemical studies on the stem bark of Murraya koenigii. Proc. Natl. Acad. Sci., India. 62, 5-9.

11. Bhattacharya, P., Chakrabory, A. 1984. 3-(1,1- dimethyl allyl)-xanthyletin from Murraya koenigii Spreng. J. Indian Chem. Soc. 61, 650-651.

12. Kaisar, M.A., Rahman, M.S., Rahman, M.Z., Hasan, C.M. and Rashid, M.A. 2011. A review on phytochemicals from some medicinal plants of Bangladesh. J. Phar. Nutri. Sci. 1, 87-95.

13. Begum, F., Haque, M.R., Nahar, K.S. and Rashid, M.A. 2014. Secondary metabolites from different extractives of Stereospermum suaveolens. Dhaka Univ. J. Pharm. Sci. 13, 31-36.

14. Sikder, A.A., Sharmin, T., Rahman, A.F.M.M., Hasan, C.M. and Rashid, M.A. 2013. Screenings of four medicinal plants of Bangladesh for bioactivities. Dhaka Univ. J. Pharm. Sci. 12, 59-62.

15. Ara, K., Haque, M.R., Kaiser, M.A., Rahman, A.H.M.M., Hasan, C.M. and Rashid, M.A. 2012. A new diarylheptanoid from Garuga pinnata Roxb. Dhaka Univ. J. Pharm. Sci. 12, 165-167. 
16. Haque, M.R., Rahman, K.M., Begum, B., Hasan, C.M. and Rashid, M.A. 2005. Secondary metabolites from Stereospermum chelonoides. Dhaka Univ. J. Pharm. Sci. 4, 61-64.

17. Sarker, S.D., Habibi, B., Sharifi, T., Asnaashari, S., Nahar, L. and Delazar A. 2008. Effect of Citrus aurantium var amara on weight change in mice. Orient. Pharm. Exp. Med. 8, 222227.

18. Santhanakrishnan, V.P., Kalpana, R., Sathishkumar, N., Narasimhan, S. and Balakumaran, C. 2011. Molecular docking study on the anti-inflammatory effect of osthol and its derivatives towards human $\mathrm{p} 38$ alpha MAP kinase. Int. J. Bioinformatics. 4, 1-4.
19. Rodighiero, P., Guiotto, A., Manzini, P., and Pastorini, G., 1979. Synthesis of isoponcimarin. Z. Naturforsch. 34b, 10101014.

20. Longhuo, W., Li, J., Guo, X., Huang, H., Hu, H. and Zhang, R. 2013. Chondroprotective evaluation of two natural coumarins: murrangatin and murracarpin. J. Intercult. Ethnopharmacol. 2, 91-98.

21. Van Wagenen, B.C., Larsen, R., Cardellina, J.H., Randazzo, D., Lidert, Z.C. and Swithenbank, C. 1993. Ulosantoin, a potent insecticide from the sponge Ulosa ruetzleri. J. Org. Chem. 58, 335-337. 